\title{
Efficacy of think tanks in influencing public policies: the case of Bangladesh
}

\author{
Major Research Paper (MRP)
}

Graduate School of Public and International Affairs University of Ottawa

Supervisor

Prof. Nipa Banerjee, PhD

Submitted by:

Ahmed Khaled Rashid

ID 5960383 


\begin{tabular}{lll}
\hline \multicolumn{2}{l}{ Chapter I Introduction } & page \\
\hline 1.1 & Background & 04 \\
\hline 1.2 & Objectives of the Paper & 05 \\
\hline 1.3 & Research Questions & 06 \\
\hline 1.4 & An outline & 06 \\
\hline 1.5 & Rationale and Significance & 07 \\
\hline 1.6 & Key assumptions & 08 \\
\hline 1.7 & Literature review & 10 \\
\hline 1.8 & Hypothesis & 13 \\
\hline 1.9 & Methodology & 14 \\
\hline
\end{tabular}

\section{Chapter II Think Tanks in Bangladesh}

$2.1 \quad$ Emergence of Think Tanks in Bangladesh 23

2.2 Typologies of think tanks in Bangladesh 26

Chapter III Issues, Factors and Dynamics of Think Tank Influence on Policy In Bangladesh

\begin{tabular}{cll}
\hline 3.1 & Think tanks and the political environment & 30 \\
\hline 3.2 & Think tanks within the civil society and the broader polity & 32 \\
\hline 3.3 & The role of bureaucracy & 34 \\
\hline 3.4 & The role of donors & 35 \\
\hline 3.5 & $\begin{array}{l}\text { Forums for policy debates / Articulation of demand for policy } \\
\text { oriented research }\end{array}$ & 37 \\
\hline 3.6 & Pervasive Corruption and think tanks & 39 \\
\hline 3.7 & Organizational factors & 40 \\
\hline Chapter IV Recommendations & 45 \\
\hline
\end{tabular}




\section{Abstract}

Think tanks refer to non-profit, non-partisan organizations engaged in the study of public policy. The number and significance of think tanks have grown in developed as well as developing countries. The objective of this paper is to study the contextual and organizational challenges and constraints faced by think tanks in Bangladesh. The paper argues that while think tanks have been visible in the policy discourse in Bangladesh through fostering policy debates and advocating policy proposals, their direct impact on policy outcomes remains limited. The methodology of this paper is secondary literature review. The papers uses elitist, statist, pluralist and institutional approaches of studying think tanks in Bangladesh. One of the key assumptions of this paper is that think tanks are a part of a larger civil society (NGOs, associations, business groups) that populate policy community and compete for visibility and influence. The paper demonstrates that the role of think tanks is undermined due to challenges emerging from the political environment that is not conducive to objective and evidence based policy suggestions. Research findings are often interpreted through the prism of politics.

Furthermore, the interface between the state and civil society, of which think tanks are part of, is not always facilitative. Often the interrelations of think tanks with bureaucracy and international donors can hinder the efficacy of think tanks in influencing policies. At the same time, a number of think tanks are institutionally weak and face challenges in funding, attracting talented researchers, and retaining long-term research focus. Nevertheless the involvement of think tanks to epistemic and policy communities are critical in generating policy ideas, fostering public debates, innovative ideas and acting as a bridge between research and policy formulation. It is imperative for think tanks to adopt new techniques for resource mobilization. The think tanks can potentially focus attention to wider policy community, increasing responsiveness to the 'end users' of research. Much more emphasis can be given to 'intermediate' influences - building capacity, wider networking and interacting with wider base of policy-makers. 


\section{CHAPTER I: INTRODUCTION}

This paper will analyze the role of think tanks (also referred to as policy research institutes) in a developing country, using Bangladesh, a developing country in south Asia, as a case study. The paper will explore a range of factors and dynamics that affect think tanks and their ability to influence public policy. The paper will review contextual factors, such as country-specific political and economic issues; organizational issues as related to financial viability and budgetary needs; and last but not the least, issues of research quality and relevance of the research undertaken by the think tanks. The paper will closely examine the nature of dynamics that facilitate and/or constrain think tanks in Bangladesh, and assess the relative importance of the roles that these dynamics play.

\subsection{Background}

Think tanks generally encompass to non-profit, non-partisan organizations engaged in the study of public policy (Abelson, 2009:9). Much like NGOs, think tanks comprise a diverse and dynamic subset of civil society (Zafarullah \& Rahman, 2002:1017). Think tanks range in size, in terms of staff, budget and vary enormously in areas of specialization, research output, and ideological orientation.

Over the last decades, there has been a rise in the number of think tanks in developed as well developing countries, underlining their growing importance and significance. Think tanks have the potentials to play a critical role in policy formulation processes, informing policy discussions and creating forum for public policy debates. This influence on policy is achieved in a number of ways, within the complex and ever changing political and bureaucratic contexts. Think tanks take critical roles in 1) playing a mediating function between the government and the public; 2 ) 
identifying, evaluating and articulating current and emerging issues, problems and proposals; 3 ) organizing and transforming issues and ideas into policy debates; 4) serving as an informed and independent voice in policy debates; and 5) providing a constructive forum for exchange of ideas and information between key stakeholders in the policy formulation process. (McGann and Weaver, 2000:3)

\subsection{Objectives of the Paper}

The broad objectives of this paper are

- To deepen understanding of the role of think tanks in a low income country encountering varied and complex challenges

- To analyze the factors that affect think tanks capacity to influence policy

- To suggest recommendations for increasing effectiveness of think tanks

Think tanks in Bangladesh provide an excellent opportunity for initiating a study with these objectives. Bangladesh is a developing country going through socio-political and economic changes. The political environment is often fractious and unstable. There are a multitude of socio-economic and governance challenges, including, corruption, high rates of poverty, and social inequality. At the same time, Bangladesh has a vibrant civil society, an active media, and a long tradition of community based organizations, taking advocacy roles. Bangladesh is reported to have more NGOs per capita than any other developing countries (Kabeer et al, 2010). Although the emergence of think tanks in Bangladesh is a relatively recent phenomenon, it currently ranks $6^{\text {th }}$ highest among Asia in terms of the numbers of think tanks in the country 
(McGann, 2012), after China, India, Japan, Taiwan, South Korea and Taiwan. Hence, based on the Bangladesh case study, this piece of research has the potential to offer important insights on the dynamics of think tanks in developing country contexts, and contribute to the growing body of literature engaged in study and analysis of the phenomenon of think tanks.

\subsection{Research Questions}

The key research questions addressed by the paper are

- What type of analytic framework could be best applied to study think tanks in Bangladesh? What are the key conceptual approaches and methods of assessing think tank effectiveness that are relevant for Bangladesh?

- What are the contextual factors (e.g. political and economic) that affect the role of think tanks?

- What are some of the institutional/organizational factors of importance that impact on think tanks?

- What are the patterns of engagements between think tanks and other stakeholders in the policy community (bureaucracy, donors)?

- What are the possible ways think tanks can increase their efficacy?

\subsection{An outline}

This paper will have four broad sections.

- First, it will outline a conceptual framework for studying and analyzing think tanks, drawing mainly from scholarly work in North America. This section will assess four 
approaches, 1) elitist, 2) pluralist, 3) statist and 4) institutional frameworks. The section will provide an outline of the key approaches and methods that are applied to assess the influence of think tanks on policy.

- Second, the paper will offer an overview of the think tanks in Bangladesh. This section will address issues related to emergence of think tanks, their key attributes and characteristics.

- Third, the paper will analyze the relevant exogenous and endogenous factors and issues to understand and explain the role of think tanks in Bangladesh.

- Finally, the paper will offer some insights and recommendations for enhancing think tank's role and efficacy, particularly the ability of the think tanks to influence policies.

\subsection{Rationale and Significance}

Think tanks first appeared in the USA and Europe at the turn of the century when organizations such as Brooking Institute (1916), Royal Institute of International (1920) were established. The term think tank was first introduced in the USA during World War II to characterize the secure environment/ space within which the civil and military experts could develop invasion plans and other military strategies. The use of the term was expanded in the 1960 s to describe other groups of experts who formulated policy recommendations (McGann \& Weaver 2000:2). Hence, the phenomenon of think tanks is considered fairly recent. As a field of study this is still new and emerging. Academic literatures and research done on think tanks are predominantly focused on think tanks in North America and Europe. Fewer academic works are found on think tanks in developing countries. Studies focusing on think tanks in Bangladesh are extremely 
limited. Hence, this paper endeavours to examine a relatively unexplored area in social science studies in the Bangladesh context. The expectation is that this paper will stimulate interests in the issue and invoke further research and studies to analyze Bangladeshi think tanks.

Undoubtedly, think tanks in Bangladesh have become quite visible. However, very little focus and attention is given on measuring or evaluating to what extent these think tanks actually influence public policies. This paper will try to address such critical questions. It will strive to identify some of the key issues and challenges facing think tanks in Bangladesh. Such issues could potentially be brought to wider fora for further analysis and debates.

Recommendations that this paper will offer for addressing these critical issues could act as a guide to scholars and practitioners alike on how the efficacy of think tanks could be bolstered and the linkages of their research, debates and dialogue to policy formulation could be enhanced.

\subsection{Key assumptions}

One of the key assumptions of this paper is that think tanks have enormous potentials to offer independent, reliable, accessible and useful information that could assist better policy making, which could positively impact on the lives of the citizens. In effect, think tanks have the potential of playing a constructive and positive role, especially in a developing country like Bangladesh. Therefore, enhancing their capacity and effectiveness in influencing policies are of utmost importance. In countries like Bangladesh, basic data and information needed for informed policy making does not always exist. Policy-relevant data need to be collected and 
analyzed so that it can be organized in a form that is usable for elected and non-elected officials. In Bangladesh, the public authorities do not always have the capacity or the resources to address such objectives and undertake credible independent research and analysis.

Another critical assumption of this paper is that think tanks are essentially a part of the civil society. McGann \& Weaver (2000: 2) note that think tanks are important elements of civil society or the third sector. The third sector concept has been developed to help distinguish non-profit, non-government institutions from both the state sector and the private for profit sector. McGann \& Weaver write, "think tanks fall in the gray areas of civil society concept since they are, organized to, at least indirectly, advise and/or assist government. It is our contention that think tanks are an integral part of the civil society and serve as an important catalyst for ideas and actions in many emerging and advanced democracies across the world" (2000:3). The notion that think tanks are part of the civil society is one of the most critical assumptions of this paper.

Although, think tanks' influence on policy is well-documented, there is no general agreement on how think tank influence can be objectively measured and what criteria can be used to do so (Abelson, 2009). Acknowledging the conceptual challenges of measuring policy influence, research in this paper will incorporate a number of context-specific criteria and factors for the required analysis, in addition to grounding the research on the mainstream literatures from academic and practical fields. 
A further important assumption of this paper is that normally policy making process does not follow a rational and linear model. There are no logical and ordered sequences of policy making phases. Rather, decision makers, accepting the limits of their situation, choose and compromise policies that satisfy, rather than maximise, the goals and objectives of the respective government programs. Officials opt for choices that are acceptable in the face of competing demands (Stone, Maxwell \& Keating, 2001:5). The assumption that research is often sidelined in the policy making processes resonates throughout this paper.

\subsection{Literature review}

As noted earlier, literature on policy research organisations in South Asia is limited (Hay \& Sudarshan, 2010: 34). This paucity is more pronounced in the case of Bangladesh, where few serious studies or academic papers focusing on think tanks have been undertaken. Studies in Bangladesh focus generally on the role of non-state actors, civil society and NGOs in the governance and policy making process.

The following reflections emerge from a literature review on Bangladeshi think tanks.

First, think tanks in Bangladesh have limited scope and space to take a meaningful role in the broader polity. This is mainly attributed to the prevailing political environment and governance norms. Elected officials are not open and often resistant to policy ideas and advice emerging from outside of the core policy networks. One set of literature (Zafarullah, 2007: Stiles, 2002) tend to support this observation by pointing to the inhibited role and contribution of the think 
tanks in the policy debate. Sobhan (2000) narrates the steady decline in effectiveness amongst the government supported think tanks in Bangladesh due to ascendancy of military regimes and norms, which undermine the work of think tanks. Politician and legislators are circumspect in playing policy entrepreneur role due to strict party discipline and highly top-down power structure.

Secondly, non-elected officials or bureaucrats are not open to ideas and proposals emerging from civil society and think tanks. In Bangladesh, like in many other post-colonial countries, the policy arena is primarily dominated by members of the bureaucrats (Administrative Cadre) who conceive and develop policies, implement and administer them and even undertake their evaluation and impact assessment. The political leaders simply endorse policies formulated by bureaucrats. While it is the duty of civil servants to advise elected officials on policy issues, it is also expected that they will be open to policy ideas generated from think tanks and other civil society organizations. Bureaucrats in Bangladesh have been generally less welcoming to policy suggestions from outside. Thus, ideas emerging from policy communities rarely, if ever, enter the policy formulation discourse; and think tanks' involvement turns merely to pretence rather than a serious exercise in participatory policy making. Therefore, one group of literature (Young, 2005: Huque, 2010: Zafarullah \& Rahman, 2008) suggest that think tanks remain less effective due to the limited space for policy discussion and advice and the lack of interest or unwillingness of policymakers to listen to other stakeholders. 
Thirdly, think tanks' capacity to influence policies depends on their institutional strengths or limitations. These factors include funding issues, policy autonomy, research capacity, leadership and governance, and effective communication of research findings. Several authors (Srivastava, 2011: Mathur, 2009: Hay \& Sudarshan, 2010) postulate that think tanks in Bangladesh face challenges in terms of research quality, maintaining a long term research agenda and funding, that undermine their ability to affect policies.

Fourthly, despite the constraints discussed above, think tanks, as part of the civil society, have played and have the potential to play a greater role in shaping policy debates and influencing policy outcomes. Historically, the third sector has contributed to promoting accountability and upholding democratic norms in Bangladesh. As such, think tanks, comprising of leading civil society representatives have advocated for better policy making and demanded appropriate policy implementation.

Authors like Zafarullah and Rahman (2002) demonstrate the prominent and extensive role of civil society, NGOs and think tank organizations. Civil society in Bangladesh is not a new institution. It had its genesis during colonial times some 240 years ago. Over the centuries, its features and focus have changed. Sometimes it has acted with a political purpose and at other times, with a social agenda. The several defining moments in Bangladesh's political history - the end of colonial rule (1947), the language movement (1952), the autonomy struggle (1969), the war of independence (1971), and anti-authoritarian resistance (1989-1990) - all featured the direct involvement of the civil society in various forms and degrees of intensity. The focus of 
civil society has been on political and social action not merely playing the role of watchdogs. Furthermore, by delivering services in education, health and other social areas, the NGOs in Bangladesh have strongly, supplemented governmental efforts at addressing poverty and other socio-economic problems.

The emergence of think tanks in Bangladesh is very much rooted in such a robust tradition of civil society movement; as part of the overall civil society movement, the think tanks wield considerable sway. This is also due the fact that a number of leading civil society actors, professionals, academics, former bureaucrats have founded and are engaged with a number of leading think tanks in Bangladesh.

\subsection{Hypothesis}

Based on the literature review and the reflections emanating, the hypothesis formulated is that - while think tanks have been visible in the policy discourse in Bangladesh through fostering policy debates and advocating policy proposals, their direct impact on policy outcomes remains limited. Think tanks have kept a watch over state affairs, facilitating debate, and creating forums for discourse on policy issues. These are important functions that greatly contribute to better and more participatory policy processes. However, the challenge to actually have a direct bearing on policy making remains daunting especially as successive governments continue to disregard democratic norms of deliberative and participatory forms of open policy making processes (Zafarullah \& Rahman, 2002: 1014). This view is supported by Carden (2009: 4), who notes, "affecting policy with good research is challenging everywhere, and especially 
difficult in developing countries," which are not always democratic and open to independent opinion.

This scenario points to a paradox of some sort - despite the robustness of civil society activism, the role and effectiveness of think tanks have not been as profound. Within this apparent contradiction, the paper will argue that the think tanks in Bangladesh have not been able to achieve their potential in having a deeper and meaningful influence in the policy arena due to the interplay of a number of factors.

The analysis will shed light on the reasons as to why this is so through closely examining a number of exogenous and endogenous factors. The analysis will focus on a number of structural issues, including the current and changing socio-political context, role of bureaucracy and donors. Analysis will also focus on some of the endogenous issues- institutional characteristics, and financial sustainability, capacity of the think tanks to determine a research agenda that is relevant in the country context and the related problematique, communication and outreach strategies, and acumen in setting priorities and implementation modalities.

\subsection{Methodology}

\subsubsection{Review of Literature}

This research relies on secondary literature. A range of articles in academic journals, books, reports, working papers, gray literature are reviewed. The first set of publications that reviewed comprise of academic and research work focused on analysis of think tanks as a phenomenon, 
their characteristics, key features and role in the policy community. Publications of some of the most recognized authors (mostly from North America) who have written on the topic of think tanks were reviewed.

The second set of publications is focused on Bangladesh. These include articles and books that cover issues related to the policy framework, role of key actors of the policy community, role of civil society, political and social conditions that affect policy processes and the functionality of think tanks in Bangladesh. Publications on civil society's role in public policy formulation processes in Bangladesh were assessed closely. Literatures on the role of donors were assessed, as most of the think tanks are funded by them. Publications that deal with the evolution of democratic processes in Bangladesh were reviewed. This is of critical importance because the assessment of think tanks is contextualized within the socio-political dynamics. Content analysis was undertaken to find common patterns.

The findings from the literature review are be analyzed using a conceptual framework, comprising four different approaches, discussed below, to address the research questions and the hypothesis.

\subsubsection{Conceptual Frameworks for Analysis of Roles of Think Tanks}

Various theoretical approaches are used to analyze the role and significance of think tanks in the policy-making community. Abelson (2009) provides a robust conceptual framework for studying think tanks. The four approaches are think tanks as policy elites, pluralist approach, statist approach, and institutional approach. 
It is evident that singling out one particular analytic approach may not be appropriate in explaining and analyzing think tanks in Bangladesh. Elements of each can be identified in the think tanks in Bangladesh. Each of the approaches has conceptual strengths and weaknesses, as well. This paper will attempt to extrapolate elements from each approach applicable in the case of Bangladesh (Chapter 3).

The analysis in this paper will draw on a number of features and attributes of the elite, pluralist, statist as well as institutional concepts. To elaborate, in trying to understand the broader role of political, social and economic contexts, this analysis will draw from elites and statist approaches; in assessing the roles of various civil society, NGO and donor organizations, a pluralist approach will be taken; in evaluating the institutional weakness and strengths of individual think tanks, it will deploy the institutional approach.

\section{Think tanks as Policy elites}

This approach views think tanks as elite organizations that rely on close ties to policy makers, particularly linkages with political, business and military leaders. These think tanks closely interact with policy elites. Many prominent and distinguished business leaders and former policy makers serve on the boards of think tanks reinforcing the image of think tanks as policy elites.

A number of prominent think tanks in Bangladesh fit this framework. The political system in Bangladesh is dominated by a select group of individuals and organizations committed to 
advancing certain political, social or economic agenda. Some think tanks maintain close ties with these authoritative individuals. This phenomenon explains why some institutes in Bangladesh enjoy more visibility and influence than others. One of the leading think tanks in Bangladesh, Center for Policy Dialogue (CPD) enjoys close ties with government and business leaders. Moreover, the societal and political positions of its Board of Trustees clearly reflect this disposition. These trustees comprise representatives from leading businesses, NGOs, lawyers, former senior bureaucrats and even a Nobel Laureate. Another well reputed think tank in Bangladesh, Institute of International and Strategic Studies (BIISS), is led by a serving Major General. The consequence is that the policy work of BIISS is closely tied to the perspectives of military elites of the country. But close ties to government policy makers have not necessarily resulted in actual policy influence.

On the other hand, certain think tanks in Bangladesh have little connection or access to the ruling elites. These organizations rely on intellectual expertise of its scholars and advocacy to reach across to policy makers.

An analysis of the think tanks dominated by policy elites offer us notable insights on how certain think tanks in Bangladesh function but the effect of the policy elite community does not necessarily account for the totality of the effectiveness of the think tank community and their policy influence.

\section{The pluralist approach}


The pluralist approach considers think tanks to be one of many other groups, such as interest groups, trade unions, human rights organizations, NGOs and donors that are striving to influence public policy debates. Many different types of organizations populate such a policy community and members of these organisations vie for attention of policy makers as well as that of the public. Think tanks compete with this set of organizations. This approach views public policy not as a reflection of a specific government mandate but rather as an outcome of group competition.

Some elements of pluralist approach could be relevant in the case of Bangladesh. Think tanks have assumed increased importance in Bangladesh, but they remain one of many organizations competing for visibility and influence. A number of large NGOs in Bangladesh, like BRAC, other civil society organizations, media, associations and forums and even the donors try to influence public policy with their work by adopting different strategies not too dissimilar from think tanks.

Interestingly, an analysis of this approach is able to find no explanation for why some types of organizations (using populist approach) are able to influence policy and others not. It is clear, however, that think tanks, due to some of their unique attributes, such as special substance knowledge and expertise and policy relevant research competence are better equipped to influence policy making. On the other hand, large NGOs or professional associations (such as lawyers' association) despite having a certain level of influence in policy circles are unable to have effective influence on policy making, as such.

\section{A statist approach}


A statist approach postulates that while the public and civil society can impose some pressure/restraint on the actions of bureaucracy and elected officials, the state retains a degree of autonomy and works according to its own logic. This approach helps to explain and analyze the extent of influence that think tanks can have on government policies. Relative to the state's authority and autonomy, the think tanks and NGOs play a modest role in shaping public policy. This approach suggests that the state can and does act independently of external pressures. It is very difficult to impose the agenda of the think tanks or civil society organizations on the state.

Statist approach offers some explanation as to why some think tank employees are asked to work for the government. The state tries to co-opt individuals from civil society and think tanks organizations as the state perceives that these individuals can have considerable influence on public opinion. Co-opting such figureheads can also promote legitimacy of the state's endeavours. An example in Bangladesh was when the Executive Director of leading think tank served as Bangladesh's Permanent Representative to Geneva from 2007 to 2009. Think tanks senior staffs are also often coopted in a number of high-level consultative bodies of the Government of Bangladesh. The statist approach is relevant for Bangladesh to a great extent and it does shed a light on the processes of influence on policy.

\section{Institutional approach}

Three distinct approaches to study think tanks as institutions have emerged. The first approach focuses on specific think tanks, and evolution and changing roles of think tanks in particular countries. This provides a wealth of information on nature and mandate of organizations. 
The second institutional approach is related to involvement of think tanks to epistemic or policy communities. These communities, comprising individuals and organizations, by virtue of their policy expertise, are invited to participate in policy discussions with government decision makers. The formation of epistemic communities is seen as a critical element in policy formulation. It allows analysts to focus on specific policy issues- (child labor policies is an instance). The key organizations and individuals are identified and invited to join the epistemic policy community to discuss and share their thoughts with policy makers. This approach offers a better insight into the nature of policy making process itself. It allows observers to compare what policy advice was given and what policy decisions were actually made. However, the approach does not help us to appropriately measure the impact of think tanks within or outside the policy community on policy processes.

The third approach puts emphasis on how groups wanting to influence policy at different stages of the policy cycle. Not all think tanks engage in different stages of the policy cycle: issues articulation, policy formulation and policy implementation. Some think tanks are interested in placing an issue on the agenda by articulating concerns, while others enter the cycle at later stages. This framework recognizes the diversity of think tanks within a country, including Bangladesh. Think tanks in Bangladesh have different strategies and scopes to intervene at different stages of the policy cycle.

\subsubsection{Approaches to assessing think tank 'influence'}

In order to assess think tanks' influence in Bangladesh, this paper will make use of a range of approaches. Evaluating think tank influence is inherently a difficult task (Abelson, 2009:90). Scholars and practitioners have different perceptions of what constitutes think tank influence. 
What makes evaluation more difficult is that policy makers, academics and journalists who use think tank publications or attend conferences, invariably have different impressions of how useful and relevant their work has been.

Furthermore, there are a number of methodological issues in trying to measure influence. A plethora of organizations and individuals try to influence policies through various channels. Tracing the actual origin of the seed of a policy idea and its critical contributions to the policy process is difficult to an individual researcher or organization.

Similarly, it can take a long time for actual influence on policy to occur from the initial publication or presentation of research findings by a think tank. If a long time elapses between the policy formulation and implementation from the time the policy idea was generated, it becomes difficult to link the actual policy to the specific research activity of a think tank.

Furthermore, policy ideas also originate outside of the think tank or NGO communities. Considering the nature of democracy and the numerous players involved in trying to influence government policy actions, crediting an institution or actor as responsible for any one particular outcome is often considered unreasonable (McNutt \& Marchildon, 2009: 220). Think tanks exercise different types of influence on different stages of policy making cycle. Numerous measures and indicators are used to assess the influence. Some argue that the extent and volume of media exposure or the number of publications are indicative of the influence. Some think tanks rely on other performance indicators, such as number of staff who are appointed in government or nominated in high level policy making committees or the size of the budget (Abelson, 2009). However, there are potential pitfalls in relying on quantitative 
assessment of think tank performance (such as number of conferences held by a think tank, or number of publications). The most visible think tanks measured with these indicators may not necessarily be the most influential (Abelson, 2009:93).

Unlike the government ministries, all of which exercise power, the policy analysis industry is engaged in policy dialogue. It is through these conversations and debates that think tanks shape the process of spreading influence to various members of the policy community. Hence, quality of policy debates can be considered an important indicator of influence.

Think tanks' influence extends well beyond direct impact on specific policies to include more intangible forms of influence. Specifically, think tanks can nurture public debate and opinion, enlarge the array of policy options, raise new questions, and expand and strengthen policy makers' capacities (Carden, 2009: 20-21). Carden extends the argument that the most meaningful and lasting influence is less about specific policy change than about building capacity, among researchers and policy people, to produce and apply knowledge for better development results.

This paper will not adhere to a rigid definition of think tank influence. Think tank influence will incorporate issues such as, dissemination of think tank research findings and results, contribution to the public debate and opinion, impact on certain public policies, enlarging the array of policy options available, and increasing the policy makers' and other actors' capacities. 


\section{Chapter II: THINK TANKS IN BANGLADESH}

Since independence in 1971, Bangladesh has made some progress in bringing positive changes in various sectors, although, overall, steady and consistent progress has not been possible. For the first two decades, political power alternated between elected civilian governments and military (or semi military) rule. The restoration of parliamentary democracy in 1991 did not significantly change the posture of politicians and parties, the performance of the bureaucracy and the conduct of the judiciary. Despite, four successive elections (1991, 1996, 2001 and 2009), assessed as somewhat free and fair, the political system has remained fragmented and unstable. However, certain social, political and economic patterns of change are evident, such as, an emerging middle class, an essentially two party political system and a degree of economic stability. Progress in the fields of health, education and poverty reduction has been commendable. However, issues related to accountability and transparency continue to influence the political and administrative systems (Zafarullah \& Rahman, 2008: 740). Successive governments have found it challenging to create the conditions for and enhancing sound governance in the country.

\subsection{Emergence of Think Tanks in Bangladesh}

In the last two decades of the twentieth century, think tanks have proliferated dramatically. Countries where think tanks were already present, such as the USA, Britain, Sweden, Canada, Japan, Austria and Germany, witnessed further organizational growth. Democratic consolidation, economic development and greater prospects of political stability in Latin America and Asia provided fertile conditions for think tank development (Stone, 2007, 264). 
This trend is observable in Bangladesh as well, which has witnessed a steady increase in the number of think tanks. Particularly, after the restoration of democracy in 1991, the proliferation of think tanks gained momentum. The growth was noteworthy in the 2000 s and continues at the present time. However, the exact number of think tanks in Bangladesh is difficult to determine. McGann (2012) reports that there are 34 think tanks in Bangladesh. Another challenge is that conceptually think tanks are defined in a number of different ways and such lists are likely to vary significantly according to the definitions.

The emergence of think tanks in Bangladesh is rooted in the strong civil society tradition in Bangladesh. As noted earlier, this paper grounds the emergence of think tanks in Bangladesh within the broader framework of civil society development and actions. These civil society organizations and associations, ranging from sports teams to labor unions, are occupying the space between the government and the citizens. Think tanks in Bangladesh, originated from cohorts of policy analysts, representing neither the public, nor the private sector. They comprised part and parcel of the civil society (McGann \& Sabatini, 2011: 13).

Sobhan (2000) narrates the evolution of think tanks in Bangladesh as a process distinct from what we observe in USA or Canada. The trend originated in the leading public universities, pioneered by socials scientists and economists, who would be involved in pedagogical and research work. Policy influence was a by-product of their endeavor of teaching and more fundamental research. In particular, the Department of Economics of the University of Dhaka was successful on significantly influencing the political opinion, even though it did not have the 
institutional structure of a think tank, as normally conceived. Sobhan underscores the political context of the pre-Liberation period in Bangladesh, where there was a need for advice to those who were engaged in directing policy. Therefore, the emergence of think tanks was to a large extent demand driven.

The emergence of think tanks as exclusive institutions influencing public policy is a recent phenomenon (Sobhan, 2000). In the Indian subcontinent (India, Pakistan and Bangladesh), the trend occurred in 1950s and 1960s. In Bangladesh, think tanks became noticeable as part of the intellectual landscape after its independence from Pakistan. However, the numbers of think tanks were very few at such times.

The governance agenda emphasized by the donors and international institutions helped facilitate the growth in the numbers of think tanks in Bangladesh. This process started in the 1990s, as development agencies such as the World Bank started to heighten the need for 'better governance' as a crucial component of development and change. This increased attention to the broad concept of 'governance' can be considered as one of the most significant changes to development ideology and aid practice in recent years, because it moved development thinking into a stronger acknowledgement of the importance of power, institutions, accountability and legitimacy. And in doing so, it acknowledged the importance of non-governmental actors, defined in terms of 'third sector', or 'civil society' (Lewis, 2010: 335). The think tanks in Bangladesh are very much rooted in this trend and the good governance theme percolates in the work of a significant number of think tanks. 


\subsection{Typologies of think tanks}

There are numerous typologies of think tanks proposed by scholars and practitioners. Sobhan (2000) divided think tanks in South Asia in three groups, 1) exclusively funded by government, 2) partially/ indirectly funded by government, 3) privately funded.

This paper employs the typology put forward by McGann \& Johnson (2005:14). They offer a broad categorization of think tanks in the global context. These categories to group think tanks in Bangladesh are analyzed below:

\section{Government affiliated or quasi-governmental}

Government affiliated think tanks are part of the government structure. Quasi-governmental think tanks are funded by government grants but are not part of the government structure. Bangladesh Institute of Development Studies (BIDS), the first and premier think tank in Bangladesh, is a public autonomous organization. Initially, funding for BIDS was made through regular government budgetary support. In 1983, the Government created an endowment fund to ensure a source of recurring revenue for running the Institute, thereby reducing its dependence on regular budgetary support, and enabling BIDS to enjoy more functional autonomy. In 2009, the Government provided a Research Endowment Fund of Bangladeshi Taka 200 million (CAD\$ 2.5 million, as per May 2012 exchange rate) to support core institutional research of BIDS. Some donor agencies and foundations also provide resources for its activities (BIDS, 2012). Other notable government affiliated think tanks are Bangladesh 
Institute of International and Strategic Studies (BIISS) and Bangladesh Institute of Law and International Affairs (BILIA). All of these organizations mobilize external funds.

\section{Autonomous and independent / quasi-independent}

Autonomous and independent think tanks have independence from any one interest group or donor and are autonomous in its operation and funding from government. Quasi-independent organizations are autonomous from government but have affiliation with some groups, donors, or contracting agency that provide funding and have influence over operations of the think tanks.

The majority of the think tanks in Bangladesh fall in this category and straddle the categories of independent and quasi-independent. Most of these institutions are generally autonomous in operation but rely on contract or commissioned work.

A number of these institutes solicit and obtain funds from donor agencies to carry out their own research work, which helps them to pursue their own research agenda.

The period, from the country's independence in 1971 through the 1990s, marked a steady growth in the number of these think tanks. Notable among these are:

- $\quad$ Centre for Urban Studies (CUS), established 1972

- Bangladesh Unnayan Parishad (BUP), established 1980

- $\quad$ Centre For Development Research, Bangladesh (CDRB), established 1982

- Unnayan Shamannay, established 1994

- $\quad$ Centre for Policy Dialogue (CPD), established 1995

- $\quad$ Power and Participation Research Centre (PPRC), established 1996 
The rapid growth in the number of these types of think tanks in Bangladesh occurred during the 2000s. These think tanks in Bangladesh represent a wide array of thematic focus as well as institutional capacities.

\section{University affiliated}

In Bangladesh, numerous policy research institutes affiliated with private and public universities operate. A significant number of these have purely academic focus and little interest in influencing policy actions. With the proliferation of private universities, the number of university affiliated policy research centers are increasing. Notable among some of these are Centre for Development and Policy Research (CDPR) at University of Dhaka, Institute of Governance Studies at BRAC University, etc.

\section{Political party affiliated}

These centers are formally affiliated with a political party. While these types of organizations exist in Bangladesh, they are often very limited in their functions and lack visibility. Examples include Center for Research and Information (CRI), which is affiliated with political party Bangladesh Awami League.

This chapter attempted to provide insights on some key features of the policy context (from the policy makers and civil society perspectives) within which the think tanks in Bangladesh have emerged and are functioning. We observe that while there are some challenges in terms of the policy processes, various types of think tanks have cropped up in the country. The typologies listed in this chapter are illustrative rather than comprehensive. Furthermore, the distinctions between each group can sometimes be blurred. 
One key conclusion that can be extrapolated is that virtually none of the think tanks can be termed completely independent or autonomous from government or other interest groups or donors. McGann and Johnson (2005:14) note, 'for think tanks, substantive independence from government and private sphere is highly uncommon.' Potentials for operation of ideal "free thinking" independent think tanks is little in the Bangladesh context. The dynamics of policy research organizations in Bangladesh are often reflective of the political climate and contextual factors, which are elaborated further in the next chapter. 


\section{Chapter III: ISSUES, FACTORS AND DYNAMICS OF THINK TANK}

\section{INFLUENCE ON POLICY IN BANGLADESH}

This chapter reflects on the dynamics of politics, civil society and their interrelations with various actors that have implications for think tanks' role and effectiveness in influencing public policies. In particular, this chapter examines factors such as the political environment, think tanks' role as part of the civil society, the roles of bureaucracy, donors, etc. to assess the overall role of think tanks. It also analyzes some of the internal organizational factors, such as funding, that have impact on think tanks' effectiveness.

\subsection{Think tanks and the political environment}

The political context has a strong influence on the potential role of policy research institutions (Hay \& Sudarshan, 2010:35). The structure and operations of political institutions are critical determinants of the level of activity and type of think tanks in a given country. Governments that resist the voicing of independent opinions and any form of policy dissent are least likely to have a flourishing think tank sector (McGann \& Weaver, 2000:13).

Since independence, Bangladesh has undergone prolonged periods of military regimes. Think tanks, thus, functioned under considerable constraints in terms of offering objective and independent analysis of policies. After the restoration of democracy in the country in 1991, the framework conditions for think tanks were definitely more favorable. However, certain subtle 
attributes of political institutions continue to affect prospects of think tank development. Power and authority within the party as well as the government is monopolized by the top echelons of leadership. A highly centralized power structure tends to restrain possible sources of policy initiatives. Sources are neither numerous nor diverse.

The value of think tanks' research and advocacy activities depends on the extent to which the country is polarized along partisan, ideological, ethnic, or other lines (McGann and Weaver, 2000:18). Bangladeshi society, intelligentsia, and almost every spheres of public life are divided along party lines. The two parties, Bangladesh Nationalist Party (BNP) and Bangladesh Awami (People's) League, which alternated power since 1991, have acrimonious relations. Objective and evidence-based policy recommendations are difficult to inculcate in this confrontational political milieu, narrowly confined in two parties, not in a multi-party system. Think tanks in Bangladesh strive to base their influence on a claim to neutral expertise that crosses ideological divisions. However, given the deep-rooted and pervasive nature of the hostile relationship between the main political parties, think tanks find it difficult to insulate themselves.

In the South Asian countries, research findings in the public domain are often interpreted through the prism of politics (Hay \& Sudarshan, 2010: 34). Therefore, objective assessment of think tanks policy research does not take place. In polarized environments, claims of neutral expertise are not taken seriously by politicians or the citizens. Research is perceived as guided by hidden partisan or ideological agenda. 


\subsection{Think tanks within the civil society and the broader polity}

The nature of state institutions, political competition, and composition of civil society have impact on how the policy context is shaped and to what extent policies can be influenced from outside. In developing countries, the full potential for NGOs and civil society's role in policy implementation has not been tapped. Brinkerhoff $(1999,65)$ postulates that factors nurtured by both the state and civil society limit this potential. The statist approach discussed earlier conforms to this view.

In Bangladesh, the power relation between the civil society and state has not always been positive and constructive. On one hand, the presence and stature of civil society organizations (NGOs, think tanks) have expanded dramatically. This is, in part, due to the funding and support provided by the donors. Civil society and think tank leaders routinely sit in national policy bodies, advise ministers and other senior officials. Prominent figures of the civil society and think tanks have served as advisors of the Caretaker Government. On the other hand, the rise of civil society is also perceived as threat to the state (Stiles, 2002: 140). Thus, the state tries to engage with important civil society organizations and leaders.

The state expects to acquire some new allies from the civil societies. Sometimes the state tries to politicize and co-opt civil society actors. If the state fails to co-opt the civil society members, the state might try to isolate and demonize those that do not join. Under such conditions, the civil society often struggles to maintain neutrality and tries to stay away from the centers of power. 
The implication of this dynamic for think tanks is clear. Just like other civil society actors, the think tanks remain under close scrutiny of the state. The state tries to influence the think tanks in various ways so that these organizations favor the government. This does not imply that all Bangladeshi think tanks are pressurized and politicized. However, this does indicate the constraints they face as part of the civil society in a developing county context.

States in more mature democratic societies promote ideas and activism emanating from the civil society actors to complement the government initiatives. For example, states in the West engage civil society actors in various informal and formal consultations before making policy decisions. However, in countries like Bangladesh, the state does not promote active participation of the civil society. There are hardly any systematic mechanisms for the state to incorporate civil society actors in its decision making processes. Also, the state remains generally non-receptive to policy advice from civil society (as well as think tanks).

This phenomenon is supported by authors like Rahman (2006). Rahman, whose main focus was NGOs in Bangladesh, argues that the NGO sector in Bangladesh, over the last decades, has shifted away from a social mobilization to a service delivery paradigm. The author contends that the shift away from political activism and social mobilization is best explained not as an intrinsic weakness of the NGOs themselves, but as a response by NGOs to a local socio-political climate inimical to civil society activism. Think tanks, being a part of the broader civil society movement, face similar challenges emanating from a non-receptive state apparatus. 


\subsection{The role of bureaucracy}

Bureaucrats are primarily responsible for assisting in the formulation of public policies. However, in Bangladesh, the civil service is often politicized and functions with continued political interference in its work. Partisan conflict within the bureaucracy has made the administrative process extremely complex. Furthermore, within the civil service, inter-cadre conflicts for supremacy produce discord, and mal-coordination among ministries and departments (Zafarullah \& Rahman, 2008: 744).

Values such as conservatism, caution, scepticism, elitism and even touches of arrogance mark the bureaucracy of Bangladesh. Government officials believe that the business of government can be fully understood only by themselves. Bureaucrats consider themselves as the highly specialised exclusive source of policy advice and guidance for the government and their 'proven' experience and proficiency in accomplishing policy goals. They insist on playing the key role in policy formulation and seek absolute discretion in implementing them (Zafarullah, 2007:163). Such elitist bureaucrats are not inclined to be open or receptive to ideas from think tanks in policy debates.

Huque (2010:6) notes that politicization of the bureaucracy led to a number of adverse effects. The consequences included bureaucratic domination over policy decisions, factionalism and micro-bureaucracies, and bureaucratic intemperance and intransigence. These institutional characteristics and mind-set of the bureaucracy help to explain why policy proposals emanating from think tanks are often rejected. 
Admittedly, advising and assisting politicians in formulating and implementing policies are amongst the high priority functions of the bureaucrats. However, it is unfortunate that in Bangladesh the bureaucracies seem unwilling to include and incorporate ideas and proposals put forward by external stakeholders, even if the external actors have competence and special expertise in certain areas.

\subsection{The role of donors}

Since the year of Independence in 1971, Bangladesh received substantial foreign aid. The dynamics of relations between aid giving and receiving countries is often complex. This is no exception in the case of Bangladesh. As intimated in the pluralist approach, donors are one of actors who try to have an impact on policy making processes. In Bangladesh, over the past decades, donors have attempted to influence the domestic policy agenda (Sobhan, 2002). Foreign aid is often tied to specific policy recommendations of the donors. Sometimes the donors added conditions to providing aid. Many of these conditions contain policy recommendations that the recipient government is obliged to address. Furthermore, such conditionality tends to be predominantly based on donor priorities and what the donor perceives as important for the recipient country's development. Oftentimes donors' priorities bear little relevance to the country's needs.

In the case of Bangladesh, overtime, this has resulted in gradual erosion of ownership of policy agendas. The Bangladeshi governments rely on donor partners to legitimize and carry forward its own development and policy agenda. As a result, the commitment and capacity to indigenize policy making has been a challenge. It must be noted that not all foreign donors 
insist on shaping and influencing the recipient government's policy priorities. But a significant number of donors have influenced how policy focus of the recipient countries should be defined.

As the recipient government finds itself in a difficult position to set its own policy agenda, the government is severely limited in its scope to seek policy advice from think tanks. In such a context, the role of think tanks in feeding policy processes remains limited. The think tanks perceive it meaningless to pursue a certain policy course due to government's incapacity to uptake their policy advice.

Increasing emphasis is being placed by donors on issues of market access, foreign direct investment and debt-rescheduling (Sobhan, 2002: 546). On these issues, the donors have reoriented themselves as policy advisers rather than resource providers. Donors also call in expatriate consultants, and thus the local expertise and research capacities of think tanks are not drawn upon.

There is another dynamic vis-à-vis the donors that affect the think tanks. International donor agencies (government and non-government) provide the lion's share of resources for the think tanks in Bangladesh. This contributes to financial sustainability of the think tanks and sometimes has the spin off effects on enhancing organizational capacities, and research qualities of these institutions.

However, the donors fund the think tanks to research and promote their own set of policy agenda and priorities. Often times such research is more attuned to donor conceived strategies and lack relevance in the domestic political context. Sobhan (2000:445) cites the example of Bangladesh Institute of Development Studies (BIDS) in this context. In the initial stages, BIDS 
retained credibility to design its own research projects originating from its internally determined research priorities. But as BIDS's income depreciated, the institute became more dependent on contracted research originating from research needs of the donor agencies. Presently BIDS addresses issues that would not normally be included in the research priorities of the organization. BIDS appears to have surrendered control of its research agenda in difference to donor wishes. Notably, therefore, donor funding may be critical for think tank sustainability but it can and does undermine the think tanks' ability to set their own research agendas and thus influence policies. The conclusion is that donor dependency of both the national government and that of the think tanks in Bangladesh potentially contribute to undermining think tanks' effectiveness. However, core funding provided to think tanks by donors (e.g. Think Tank Initiative of International Development Research Center, Canada) allows think tanks to strengthen different aspects of the organization and contribute to their sustainability.

\subsection{Forums for policy debates / Articulation of demand for policy oriented research}

Bangladeshi think tanks have undoubtedly contributed to the policy debates in various forms and shapes. However, one challenge has been that there are few mechanisms in place to allow

organizations to openly advocate their knowledge and ideas to important policymakers (such as bureaucracies or parliamentary committees) with expectations of policy results. 
Sobhan (2000) notes that research oriented think tanks like BIDS produced high quality research, but often times these never reach the intended audiences. Only a handful of Bangladeshi think tanks have well-crafted communication strategies and dedicated public relations staff. However, increasingly more and more think tanks are realizing the importance of communication as a tool for reaching out to policy makers and wider audiences.

On the other hand, policy makers also have failed to make consistent efforts to effectively articulate their demand for research for policy making. This was a marked contrast to preliberation period, when political leadership looked for policy advice from academia for mobilizing struggle for equality and independence.

In the current context in Bangladesh, the fora for bringing together policy makers and parliamentarians with stakeholders, as well as professionals who undertake research to collectively address policy concerns remain limited. An equally important factor is the design of policy discussion forums. For sustaining policy ownership in a developing country like Bangladesh, it is imperative to encompass a wider set of policy communities, including the opposition parties, business communities, social actors and community leaders, media etc. Organizing such common forum is, however, difficult due to the politically confrontational and a socially divisive milieu. Various constituents of policy making process operate within their own isolated enclaves. Thus, the volume and diversity of dialogues between policy communities remain limited. 
Centre for Policy Dialogue (CPD), one of the leading think tanks in Bangladesh, primarily emerged to fill up the vacuum of dialogue. Presently a number of think tanks emphasize the potential benefits of holding policy specific dialogues, where think tanks present their research findings and policy analysis and policy makers articulate their needs for research and policy options in a systematic way. Such inclusive dialogues enable all the stakeholders to take forward the issues by building ownership and consensus.

At the same time, in certain topics, the policy makers tend to be inundated with reports from numerous sources, including materials prepared by think tanks and donor-sponsored consultants. Depending on topic and relevance, very few reports command serious attention within the government. Most of these reports remain unread or read only at a lower level of the bureaucracy (Sobhan, 2000: 439). Thus, it becomes a challenge for think tanks to ensure that their inputs are read by key policy makers and not entirely lost within an avalanche of information.

\subsection{Pervasive Corruption and think tanks}

Corruption in Bangladesh is widespread and institutionalised. Transparency International ranked Bangladesh as the most corrupt country in the world for five consecutive years from 2001 to 2005. Corruption and abuse of public office for private gain, has affected the quality of administrative decisions, actions and policy making (Huque, 2010:3). 
Corruption is not merely limited to the bureaucracy, but involves politicians, businessmen, professionals and military personnel. In such a context, there is little incentive for these groups, often constituting the policy networks and policy community, to change the status quo and allow evidence based policy advice of think tanks to be incorporated and adopted. Think tanks, from their perspective, can strive to raise policy issues based on scientific research and evidence-based policy analysis. However, corrupt officials are not inclined to allow such objective analysis to influence their decision processes. And corruption in the government is sometimes so deep-rooted that, think tanks' efforts to influence and pressurize government institutions have little impact.

\subsection{Organizational factors}

Organizational issues and factors are the key to understanding the phenomenon of think tanks and evaluating their effectiveness, as reflected in the institutional approach (discussed in Section 1.9.2). Some of the key organizational issues that are relevant for think tanks in Bangladesh include financial sustainability, maintaining autonomy in all areas from selection of research agenda to publication and communication of findings etc. These issues are discussed below.

Financial sustainability: Financial sustainability is perhaps the biggest challenge for think tanks across the globe. The situation is more acute in developing countries in the South. McGann and Weaver (2000:16) observe, "In the Middle East, Africa, Asia and Latin America, think tanks face the problem of not having either tax laws or philanthropic traditions that favor support for independent public policy research." Funding is also a major issue for think tanks in Bangladesh. 
Much of the growth of think tanks is attributable to donor funding. Apart from some government funded think tanks, most of the think tanks depend on consultancy contracts from donors and other agencies.

Sobhan (2000) identifies financial sustainability as the major challenge facing think tanks in Bangladesh. Sobhan narrates how BIDS, a public think tank, eventually had to take recourse form external sources. Originally, BIDS had been funded through the national budget. An endowment fund was created later which helped generate recurring income for the organization. However, interest earned from the fund through bank fixed deposit was inadequate to sustain the activities of the organization. BIDS became increasingly dependent on project funding, occasionally from Bangladeshi government but mostly from donors. Without steady sources of income, some think tanks struggle to recruit and retain qualified staff to carry out research initiatives. Funding constraints, thus, can affect quality of research outputs. Indeed, an International Development Research Center (IDRC) survey (2011) reveals that the two most important elements that stakeholders believe can improve think tank's performance are greater availability of trained / experienced staff and higher quality of research.

Maintaining long term research agenda: Majority of the think tanks in Bangladesh are dependent on funding of individual research projects. Donor agencies and other organizations contract think tanks to carry out specific research initiatives. These types of contracted research originate from specific requirements of the donor agencies. Thus, some think tanks function more like consultancy agencies, who for fund raising purposes are obliged to accept the terms 
of reference that are offered by the donors. The majority of the policy research organizations in Bangladesh function as a hybrid of think tank that set and retain a sense of their own research agenda and those who do consultancy type of work, with terms of reference set by external agencies.

Greater dependence on finances derived from donor funded research projects makes it difficult to retain focus on a long- term thematic agenda. Think tanks are forced to take up research projects in a variety of thematic areas, which donors are interested in. Sometimes the think tanks even depart from their core research interests and competencies. Furthermore, there are little synergies between the various projects for which consultancy contracts are taken up by the think tanks. Long term work on any specific theme is difficult under these circumstances. Project-based funding can also limit scopes to build longer term organisational capacities (Hay \& Sudarshan, 2010: 35). This is symptomatic of the think tanks in Bangladesh.

There are exceptions, however. Think tanks like Centre for Policy Dialogue have solicited and received financing from the donors. But much of its research focus have been articulated and designed within the organization. Donor funds were mobilized to underwrite CPD's own program.

Leadership: A few of the think tanks in Bangladesh rely almost entirely on the founding chief executive or director for funding and for intellectual support. These organizations often do not possess adequate institutional capacity. They constantly seek funding from donors or 
sometimes the government. Personal connection of the head of the organization becomes an important variable in ensuring sustainability.

Maintaining structural autonomy: Structural autonomy is a specific issue for public think tanks because of the nature of their affiliation with the government. These organizations encounter the challenge of retaining policy autonomy, and manage the relations with government in power. Especially, public think tanks have found it extremely difficult to be critical of government policies. During the early 1990s, the Bangladeshi government perceived BIDS, to be its opponent both ideologically as well as politically (Sobhan, 2000: 436).

Communication: Communication is a challenge for many think tanks in Bangladesh. Some of the institutions have not developed the skills needed to design and implement effective communication strategies. In some instances, the problem arises because certain researchers do not perceive the need to actively communicate their findings. They see themselves as researchers and not as communicators or advocates of their research. There might be circumstances in which researchers do want to communicate their research, but they may lack the skills to do it. Time or financial constraints may also play a part.

Some of the other institutional challenges include the capacity to handle the managerial and technical tasks involved in implementation of partnerships, scaling up, policy monitoring, responsiveness to policy contexts, and so forth. Issues related to governance and professional 
integrity, as well, have cropped up with respect to think tanks in Bangladesh. These factors can undermine research quality and affect organizations' credibility.

This chapter addressed the research questions related to the contextual and organizational factors and patterns of engagements between think tanks and other stakeholders in the policy community. It highlighted some of the issues and factors that affect think tanks' ability to influence public policies, such as the political environment, the nature and composition of state and civil society institutions and complex inter-relations with the bureaucracy and donors. At the same time, the think tanks encounter challenges in terms of their own organizational capacities that inhibit their effectiveness. This analysis helped to develop an understanding of the constraints faced by Bangladeshi think tanks. The findings support the hypothesis that while the think tanks have been visible in the policy discourse in Bangladesh, their direct impact on policy outcomes remains limited. 


\section{CHAPTER IV: RECOMMENDATIONS}

This paper illustrates that the think tanks' effectiveness is influenced and can be undermined by contextual factors and organizational weaknesses of the think tanks. At the same time, it is imperative that relevance of think tanks is evaluated within a broader framework of assessment that does not solely focus on think tanks' ability to influence government policies. Think tanks' influence can go beyond directly impacting on public policies. In addition to influencing polices, think tanks can serve as means to extend policy analytic capacities to support civil society development and human capacity development (Stone, 2004: 1). Simply focusing on gauging policy influence of think tanks is an unfair stand to take ignoring the fact that these organizations can play multiple roles.

Despite the constraints and challenges encountered by think tanks and policy research organizations in Bangladesh, there seems to be a consensus among policy makers on the positively critical role of these institutes in the policy community. IDRC's Think Tank Initiative (TTI) conducted a survey (IDRC, 2011) of policy stakeholders in three specific regions of the globe, including South Asia. Respondents included senior officials from government, NGOS, media, donor agencies, private sector and research/ academia. Those who were surveyed were active members of the national policy community who have the power to develop and influence national government policies. 
Survey results for Bangladesh reveal that respondents identified think tanks as their primary source of information. Overall, the quality of think tank research in Bangladesh is assessed very positively in comparison with other South Asian countries. Stakeholders also believe think tanks in Bangladesh excel in focusing on high priority issues.

However, the survey findings do raise some areas of challenges for the think tanks. These findings complement the analysis of this paper. For example, the stakeholders find it somewhat challenging to access information on a range of topic areas that could support their work in policy development. The respondents gave 'neutral' or 'negative' ratings rather than positive ratings on their ease of access to information from think tanks on most areas probed in the survey. Stakeholders give lower ratings to think tanks on using innovative approaches to research and partnering with other policy actors and on the value of public events. The survey results corroborate many other findings and issues identified in this paper.

The recommendations offered below are quite broad in their approach- they focus on a range of ideas from conceptual re-orientation to practical measures to augment the effectiveness of research institutions. Admittedly, a number of the analytic points are drawn from academic literature from developed countries and yet they can be relevant in the Bangladesh context.

\section{- Securing financial sustainability}

Think tanks in Bangladesh rely, to a large extent, on foreign governmental and private funding. Think tanks must look for other sources and diversification of funding. One way is to learn the techniques of fund raising and resource mobilization. One area of potential resource 
mobilization is the philanthropic sector. Philanthropy in Bangladeshis mostly based on personal charity - the Islamic tradition of zakat and sadka (Holloway, 1998:47). There are few coordinated ways in which ordinary people are encouraged and enabled to donate to civil society organizations. Think tanks can explore and promote new forms of fund raising from common but interested people. Legislative reforms for income tax benefits for charitable donations can be advocated to encourage individuals to donate funds to such organizations and gain some tax benefits. In Bangladesh, there is very little corporate funding to civil society organizations. Funding to think tanks can be promoted as a corporate social responsibility.

\section{- Increasing responsiveness and reconceptualising accountability mechanism}

In general, think tanks in Bangladesh have a good track record of maintaining standards of professionalism and management practices. Think tanks are accountable to donors or clients, and to the government in a broader sense. However, the research organizations can potentially focus attention to other stakeholders by increasing responsiveness to the wider stakeholder and policy community. The stakeholders may include 'end users' of their research and analysis who are in need of improvements in livelihoods and reduced poverty etc. End user is a term used to describe the final beneficiary of a technical innovation or policy (e.g. the farmer using a new seed variety or a farmer who benefits from a new fertilizer application). Think tanks often claim that their policy proposals will benefit certain group (e.g. farmers, exporters, small enterprises). This incurs a duty to be accountable to the claimed beneficiary. Links to claimed beneficiaries provide a source of legitimacy and credibility, particularly if the relationship is an ongoing one. Therefore, it is important to engage with the end-users in the course of the 
research itself. Engagement with end-users of an innovation or the policy-makers to discover the type of information and innovations they require, and their participation in their research process itself, will therefore be important to its ultimate adoption (Whitty, 2008: 16).

\section{- Targeting 'Intermediate' influences}

The majority of the ideas or innovations generated by think tanks may never become policy or will get 'out-competed', for whatever reason, by other ideas or imperatives. It is important to have realistic expectations about the potential for influence. Think tanks in Bangladesh can possibly focus on achieving or causing intermediate influences as well as direct changes in policy. The intermediate influences imply building capacity of chosen actors, wider networking and interaction with policy-makers, broadening horizons of others that comprise a policy network (Lindquist 2001, 23).

Bangladeshi think tanks can potentially put emphasis on expanding policy capacities by improving the knowledge/data of certain actors, developing new talent for research and analysis. Think tanks can strive to broaden policy horizons by providing opportunities for networking/learning; introduce new concepts to frame debates, put new ideas on the agenda, educating researchers and others who take up new positions with broader understanding of issues.

\section{- Engagement with a wider set of actors}

Research is more likely to be effective when policy networks and advocacy coalitions are forged. Networks allow smoother communication and transfer and visibility of information. 
This helps facilitate policy changes. It is important that the Bangladeshi research organisations engage with a wider set of actors in the system- at domestic, regional and international levels, instead of focusing simply on policy-makers. Networks are increasingly being harnessed as 'platforms for action' to generate wider support, to empower their members and to provide a space for discussion. Knowledge and innovation generated through research can be exchanged across borders. Use of research information and findings from outside the country result in exchange and transfers of ideas. (Carden and Neilson 2005, 147).

\section{- Partnerships with think tanks and using external expertise}

The leading think tanks of Bangladesh forge horizontal and vertical linkages with other regional and international think tanks. Particularly, networks among the South Asian think tanks have been highlighted by academics. Further partnerships and exchanges, import of more external expertise benefit research through cross fertilization of ideas and capacity development. Partnerships with other policy actors provide additional knowledge or expertise which does not often exist in-house. For Bangladeshi think tanks, partnerships with other think tanks create opportunities for adopting new and innovative approaches and initiatives.

Krastev (2001:32) outlines the benefits of networks among think tanks as enhancing influence, creating common grounds, bolstering legitimacy. Regional networking can also facilitate quality control and training. For example, in East Asia many think tanks are cooperating with each other to fill a gap in this part of the world by organizing regional cooperation arrangements such as the PECC (Pacific Economic Cooperation Council) as the second track of APEC (Asia 
Pacific Economic Cooperation). PECC has been a pioneer in the development of a tri-partite institution (involving business, academe, and officials in private capacity) to provide policy suggestions to governments. It was also instrumental in the creation of APEC as the formal inter-governmental institution in the wider Asia Pacific region (Wanandi, 2008).

\section{- Transparency / clarity to improve legitimacy of the research}

Think tanks and NGOs, and other civil society organizations in Bangladesh often lack credibility among political leadership. This perception is not necessarily based on factual information. The perception results from lack of knowledge of the activities of the organizations. Better transparency in operational and research activities have potentials of increasing the visibility and credibility of organizations. Transparency can be generated through use of transparent data collection methods, and other research tools and processes used. If research findings can be easily reviewed and evaluated by policy experts regularly, a strong reputation for credible research can be established. It is recognized that policy makers and researchers do not often speak the same language (Carden, 2009: 3). It is incumbent on policy researchers to systematically present their findings and proposals in an accessible and non-technical manner to generalist bureaucrats or politicians, who may have little or no academic knowledge of the subject matter.

\section{- Capacity of policy makers and media}

A study by McGann (2006) of many donors working in developing and transitional countries, point out the importance of working on the demand side of the policy advice equation as well 
as the supply side. Many of the donors felt they had been successful at establishing and building capacity of think tanks and even in sustaining them. Yet, that capacity must be improved with involvement of policymakers in the legislative and executive branches of government as well as with the media.

Hence, adopting a more holistic approach and working with both sides of the spectrum can be useful. Specifically, steps must be taken to help governments, policymakers and the media understand the value and utility of independent policy advice. Bangladesh offers great potentials for working with journalists and media in different sectors to improve knowledge and capacity for better understanding and reporting on ideas and policy proposals put forth by think tanks. 


\section{CHAPTER V: CONCLUSION}

Analysis in this paper is more illustrative than comprehensive in nature. Much more in-depth and focused analysis needs to be undertaken to assess conceptually and empirically the roles of think tanks within the policy community.

The paper analyzed the challenges and constraints the contextual factors, especially the political environment, impose on think tanks. Analysis in the paper demonstrates that the hypothesis made is acceptable -- despite being part of a strong civil society tradition, which should help earn a position of strength, Bangladeshi think tanks' efforts to influence public policies have been undermined due to unstable and problem ridden political environment and organizational weaknesses of the think tanks themselves. The paper identified politicisation and extreme bi-polar nature of political landscape as being one of the major factors hindering think tank's role. Furthermore, the paper analyzed the role of bureaucracy and donors vis-à-vis think tanks and showed how these interfaces tend to undermine think tanks' efforts to influence policies. It is also claimed that pervasive corruption in Bangladesh often does not encourage evidence based, objective assessment of policy options. In addition, organizational weaknesses (in terms of limited resources, and inability to maintain long term research agenda) of the think tanks can be hindrance to their efforts in playing a meaningful role.

Although the paper has demonstrated an inhibited role of think tanks in Bangladesh, it claims that think tanks' 'influence' ought to be assessed taking a wider and less stringent perspective. Influence should not be only measured based on 'direct policy impact'. Think tanks in 
Bangladesh have been successful in creating knowledge networks, informing discussions, creating forums for deliberations and also fostering some degree of accountability in the policy processes. These achievements must be acknowledged.

Looking ahead, there are credible reasons to be optimistic about the prospects of think tanks in Bangladesh. Undoubtedly the demand for policy expertise is likely to grow in areas such as climate change, knowledge economy, information and communication technology, global governance, etc. Policy proposals, ideas, innovative approaches from think tanks may prove to be critical in providing support to government department and agencies in policy discussions encompassing these issues. As new policy areas develop, think tanks can be expected to play the roles of not only experts but also of visionaries.

A host of other types of organizations are also now seeking policy advice and expertise. Private foundations, corporations and non-state actors are demanding high quality research, and policy analysis (Stone \& Denham, 2004: 1). It is up to the Bangladeshi think tanks to grab such opportunities and trends, to have deeper and more meaningful impact on fostering local research capacities and knowledge that can catalyze the country's development. 


\section{Reference}

Abelson, D. E. (2009). Do think tanks matter? Assessing the impact of public policy institutes. Montreal : McGill-Queen's University Press.

BIDS (2012). BIDS - A Brief History. Accesses on January 21, 2012 http://www.bids.org.bd/AboutInstitute.php?FM=2\&SM=61\&Page=About\%20Us

Brinkerhoff, D. (1999). Exploring State-Civil Society Collaboration: Policy Partnerships in Developing Countries. Nonprofit and Voluntary Sector Quarterly, 28 (4), 59-86.

Carden, F. (2009). Knowledge to policy: making the most of development research. Sage, IDRC.

Carden, F. and Neilson, S. (2005). Confluence and Influence: Building Policy Capacities in Research Networks, in Diane Stone and Simon Maxwell (eds), The Challenge of Transnational Knowledge Networks: Bridging Research and Policy in a Globalizing World. pp. 139-55. London: Routledge.

Hay, K. \& Sudarshan, R. M. (2010). Making Research Matter in South Asia. Economic and Political Weekly, XLV(3), 34-36.

Holloway, R. (1998). Supporting citizens' initiatives: Bangladesh's NGOs and society. London, UK: Intermediate Technology Publications.

Huque, A. S. (2010). Extra-bureaucratic Accountability Mechanisms and Governance in Bangladesh. Prepared for presentation at the 14th IRPSM (International Research Society for Public Management) Conference in Berne, Switzerland, April 7-9, 2010. Accessed on February 6, 2012 http://www.irspm2010.com/workshops/papers/31_extrabureaucratic.pdf

IDRC (2011). Think Tank Initiative, Policy Community Survey, South Asia. Survey conducted by Globescan.

Kabeer, N., Mahmud, S. \& Castro, J. G. I. (2010). NGOs' Strategies and the Challenge of Development and Democracy in Bangladesh. Institite of Development Studies (IDS) Working Paper 343. Retrieved on August 21, 2011 http://www.ids.ac.uk/files/dmfile/Rs343.pdf

Krastev, I. (2001). Think tanks: making and faking influence. Southeast European and Black Sea Studies, 1 (2), 17-38.

Lewis, D. (2010). Political ideologies and non-governmental organizations: an anthropological perspective. Journal of Political Ideologies, 15(3), 333-345. 
Lindquist, E. A. (2001). Discerning Policy Influence: Framework for a Strategic Evaluation of IDRC-Supported Research. Accessed on Jan 11, 2012 http://web.idrc.ca/uploads/userS/10359907080discerning policy.pdf

Mathur, K. (2009). Policy research organisations in South Asia. Centre for the Study of Law and Governance, Jawaharlal Nehru University, New Delhi.

McGann, J. G. \& Weaver, R. K. (2000). Think tanks \& civil societies: catalysts for ideas and action. New Brunswick, NJ : Transaction Publishers.

McGann, J. G., \& Johnson, E. C. (2005). Comparative think tanks, politics and public policy. Cheltenham, UK; Northampton, MA : Edward Elgar.

McGann, J. G. (2006). Best practices for funding and evaluating think tanks \& policy research. The William and Flora Hewlett Foundation. Accessed on January 13, 2012 http://www.hewlett.org/uploads/files/BestPracticesforFundingandEvaluatingThinkTank s.pdf

McGann, J. G. (2012). The global "Go-To Think Tanks" The Leading Public Policy Research Organizations in the World. Foreign Policy Research Institute. Accessed on January 1, 2012 http://www.gotothinktank.com/wp-content/uploads/2012/03/2011-Global-Go-To-ThinkTanks-Report-February-21-Edition-WITH-LETTER.pdf

McGann, J. G. and Sabatini, R. (2011). Global think tanks: policy networks and governance. London; New York : Routledge.

McNutt, K. \& Marchildon, G. (2009). Think Tanks and the Web: Measuring Visibility and Influence. Canadian Public Policy, 35(2), 219-236.

Rahman, S. (2006). Development, Democracy and the NGO Sector: Theory and Evidence from Bangladesh. Journal of Developing Societies. 22 (4), 451-473.

Stiles, K. W. (2002). Civil society by design: donors, NGOs, and the intermestic development circle in Bangladesh. Westport, Conn: Praeger.

Stone, D., Maxwell, S., Keating, M. (2001). Bridging Research and Policy. An International Workshop, Funded by the UK Department for International Development, Radcliffe House, Warwick University, 16-17 July 2001. Accessed on January 30, 2012 from http://www2.warwick.ac.uk/fac/soc/csgr/research/keytopic/other/bridging.pdf

Stone, D. and Denham A. (2004). Think tank traditions: policy research and the politics of ideas. Manchester; New York: Manchester University Press; New York. 
Stone, D. (2007). Recycling bins, garbage cans or think tanks? Three myths regarding policy analysis institutes. Public Administration, 85(2), 259-278.

Sobhan, R. (2000) Think Tanks in South Asian in Think tanks \& civil societies: catalysts for ideas and action. McGann, J. G. \& R. Kent Weaver, R. K.(ed.). New Brunswick, NJ : Transaction Publishers, c2000.

Sobhan, R. (2002). Aid Effectiveness and Policy Ownership. Development and Change, 33 (3), 539-548.

Srivastava, J. (2011). Think tanks in South Asia, Analysing the knowledge -power interface. Overseas Development Institute. Accessed on January 1, 2012 http://www.odi.org.uk/resources/docs/7530.pdf

Wanandi, J. (2008). The Importance of Think Tanks in the Twenty-first Century. Asia-Pacific Review, 15(2), 6-8.

Whitty, B. (2008). Accountability Principles for Research Organisations. One World Trust.

Young, J. (2005). Research, policy and practice: why developing countries are different. Journal of International Development, 17, 727-734.

Zafarullah, H. (2007). Bureaucratic Elitism in Bangladesh: The Predominance of Generalist Administrators. Asian Journal of Political Science, 15 (2), 161-173.

Zafarullah, H. \& Rahman, R. (2008). The impaired state: assessing state capacity and governance in Bangladesh. International Journal of Public Sector Management, 21(7), 739-752.

Zafarullah, H. \& Rahman, M. H. (2002). Human Rights, Civil Society and Nongovernmental Organizations: The Nexus in Bangladesh. Human Rights Quarterly, 24(4), 1011-1034. 